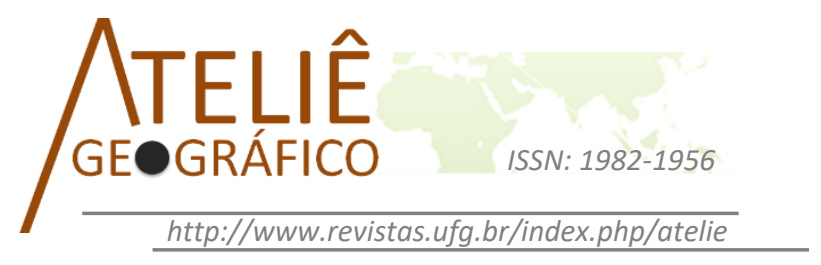

\title{
Expansão urbana e a questão fundiária: um reflexo da segregação territorial nas regiões Norte, Noroeste e Meia Ponte de Goiânia - GO
}

\author{
Urban expansion and the land question: a reflection of \\ territorial segregation in the North, Northwest and Middle \\ Bridge of Goiania's regions - GO
}

Expansión urbana y la interrogante de tierra: un reflejo de la segregación territorial en las regiones Norte, Noreste, y

Media Puente de Goiânia - GO

Helci Ferreira Ramos

Universidade Federal de Goiás - IESA/UFG

helcifg@gmail.com

Fabrizia Gioppo Nunes

Universidade Federal de Goiás - IESA/UFG

fabrizia.iesa.ufg@gmail.com

\begin{abstract}
Resumo
Tendo em vista a legalização ao direito à moradia, a presente pesquisa teve como intento central o diagnóstico e mapeamento do crescimento da malha urbana das regiões Norte, Noroeste e Meia Ponte, bem como da atual situação fundiária da posse legal de suas terras. Para alcançar tais objetivos, realizou-se um levantamento bibliográfico da ocupação histórica e social destas regiões, correlacionada, a sua periodização cartográfica. Como resultados foram gerados produtos cartográficos derivados da interpretação de imagens sensoriais, que ilustram a expansão da malha urbana entre1975 a 2015. A partir de dados da Prefeitura de Goiânia foram gerados também, mapas do processo evolutivo do loteamento do solo, entre os anos de 1950 a 2015 e da atual condição fundiária destes loteamentos. Os resultados indicam que apesar do esforço do Estado a partir da década de 90, a questão da situação fundiária até hoje não está totalmente resolvida, pois ainda são verificados alguns loteamentos e glebas de parcelamentos não aprovados por nenhuma organização pública e sem registros em cartório.
\end{abstract}

Palavras chaves: parcelamento do solo, questão fundiária, geotecnologias, urbano. 


\begin{abstract}
With a view to legalizing the right to housing, the present proposal had as its central objective, to diagnose and map the growth of the urban network of the North, Northwest and Mid Bridge regions, as well as the current land tenure situation of its land. To achieve these purposes, a bibliographic survey of the historical and social occupation of these regions was carried out, correlated, its cartographic periodization. As a result, maps derived from the interpretation of sensory products, which illustrate the expansion of the urban network between 1975 and 2015. Based on tabular data provided by the Municipality of Goiânia, maps of the evolution process of land subdivision, between the years 1950 to 2015 and the current land tenure of these land lots. Results indicate that despite the State's efforts since the 1990s, issue of the land situation to date is not fully resolved, because some parcels and parcels of land not approved by any public organization are still verified and without registration in the registry.
\end{abstract}

Keywords: land subdivision, land issue, geotechnology, urban.

\begin{abstract}
Resumen
Teniendo en vista la legalización al derecho de residir, la presente propuesta tuvo como objetivo central, diagnosticar y mapear el crecimiento de la malla urbana de las regiones Norte, Noreste y Media Puente, bien como de la actual situación de pose legal de sus tierras. Para alcanzar tales propósitos, se realizó una revisión bibliográfica de la ocupación histórica y social de las regiones, correlacionada, a la periodización cartográfica. Como resultado fueron generados mapas derivados de la interpretación de productos de sensores remotos, que ilustran la expansión de la malla urbana entre 1975 a 2015. A partir de datos entregados por la alcaldía Municipal de Goiânia, también fueron generados, mapas del proceso evolutivo de la subdivisión del suelo, entre 1950 a 2015 y de la actual condición de tierras de estas subdivisiones. Los resultados indican que a pesar del esfuerzo del Estado a partir de la década del 90, la interrogante de la situación de tierras hasta hoy no está totalmente resuelta, pues todavía son verificados algunos lotes y parcelas de subdivisiones no aprobados por ninguna organización pública y sin registros en notarias.
\end{abstract}

Palabras claves: subdivisión del suelo, interrogante de tierras, geomática, urbano.

\title{
Introdução
}

$\mathrm{O}$ adensamento populacional na maioria das cidades brasileiras aconteceu de forma totalmente desordenada, ocasionando sérios problemas no que se refere a informalidade da posse da terra, promovida pelo processo de expansão de novas moradias, em regiões de assentamentos não legalizados. Com o passar do tempo tais cidades vão se transformando, na tentativa de se adequarem às exigências da sociedade e da própria realidade de seus conflitos urbanos. Porém, ainda hoje deparamos com os chamados "espaços congestionados", espaços estes, configurados pelo impasse da concentração de renda, versus falta de oportunidades.

Neste embate, destaca-se a luta pelo direito à propriedade, caracterizada pelo interesse de agentes antagônicos em busca do parcelamento da terra e da posse fundiária. 
De um lado encontram-se os latifundiários, o Estado, as indústrias da construção civil e as grandes corporações imobiliárias, de outro, os grupos sociais dos excluídos, que fazem aflorar o movimento dos "sem-teto". Desta forma, a irregularidade dos assentamentos urbanos é cada vez mais fixada pela população carente que é incapaz de ostentar, todos os custos de um lote regularizado.

A questão da luta pelo direito à moradia, fruto da segregação territorial, já vem sendo alvo de reflexão há algum tempo. Autores com Moysés (2001, 2004 e 2005); Oliveira (2002 e 2005); Soares e Barbosa (2012); Morais (2003) e Correia (2010), destacam esse fenômeno na região noroeste de Goiânia e de seu entorno. Assim, as regiões em destaque, são regiões do município que apresentam vários problemas de loteamentos irregulares, marcados pela deficiência administrativa de aparatos púbicos.

Por se tratarem de lotes sem o devido registro legal de seus imóveis, estão sujeitos a não receberem do poder público administrativo as benfeitorias de estruturas básicas necessárias, tornando-se assim, áreas focos, do ponto de vista da regularização fundiária para garantia de qualquer intervenção urbanísticas. É importante destacar que o direito à moradia de qualidade já está previsto na Declaração Universal dos Direitos Humanos, desde 1948. Neste sentido a visualização do processo de crescimento urbano versus questão fundiária, direcionada à regularização da posse da terra, não, somente, remete a perspectiva da luta pelo direito à moradia, mais também da luta pela qualidade de vida.

Neste termo, a Lei Federal 11.977/2009 define a regularização fundiária como o "conjunto de medidas jurídicas, urbanísticas, ambientais e sociais que visam à regularização de assentamentos irregulares e à titulação de seus ocupantes, de modo a garantir o direito social à moradia, o pleno desenvolvimento das funções sociais da propriedade urbana e o direito ao meio ambiente ecologicamente equilibrado" (BRASIL, 2009).

O próprio ato da regularização fundiária é entendido como um instrumento importantíssimo da política urbana, pois como explicam Soares e Barbosa (2012), tal normativa objetiva ordenar e promover as funções sociais da cidade e da propriedade urbana, garantindo ao cidadão o direito à terra urbanizada e à moradia de qualidade. Assim, em poucas palavras, os autores op. cit. (2012) sintetizam que a regularização fundiária consiste no processo de transformar as terras urbanas, em terras urbanizadas, com infraestrutura e integradas à cidade.

Cabe salientar, que as áreas com ocupação informal ainda necessitam de estudos mais aprofundados para averiguar se são parcialmente ou totalmente irregulares e, se então, passíveis de regularização. Neste escopo, o presente trabalho, visa contribuir para essa análise na medida que realiza um diagnóstico do crescimento urbano das regiões Norte, Noroeste e Meia Ponte do município de Goiânia, bem como da atual situação fundiária da posse legal de suas terras.

Para tal avaliação, o presente estudo estará aparado por um apanhado bibliográfico sobre o histórico de ocupação dessas áreas, envolvendo uma correlação com 
a periodização cartográfica, do crescimento da malha urbana e da espacialização do parcelamento do solo e situação fundiária. Para tanto, foram gerados mapas derivados da interpretação de produtos sensoriais, que ilustram a expansão da malha urbana entre os períodos de 1975 a 2015. A partir de dados tabulares cedidos pela Prefeitura Municipal de Goiânia, foram gerados também, mapas do processo evolutivo do loteamento do solo, entre os anos de 1950 a 2015 e da atual condição fundiária.

\section{Área de estudo}

A área de estudo corresponde ao recorte espacial das regiões Norte, Noroeste e Meia Ponte do município de Goiânia (Figura 01). Fundada no ano de 1933, com o apoio do Presidente Getúlio Vargas, inicialmente a capital foi planejada para comportar 50.000 habitantes. Mesmo assim, dados da Prefeitura de Goiânia (2008) revelam, que na década de 1950 o crescimento da população total do município já ultrapassava a 185\%.

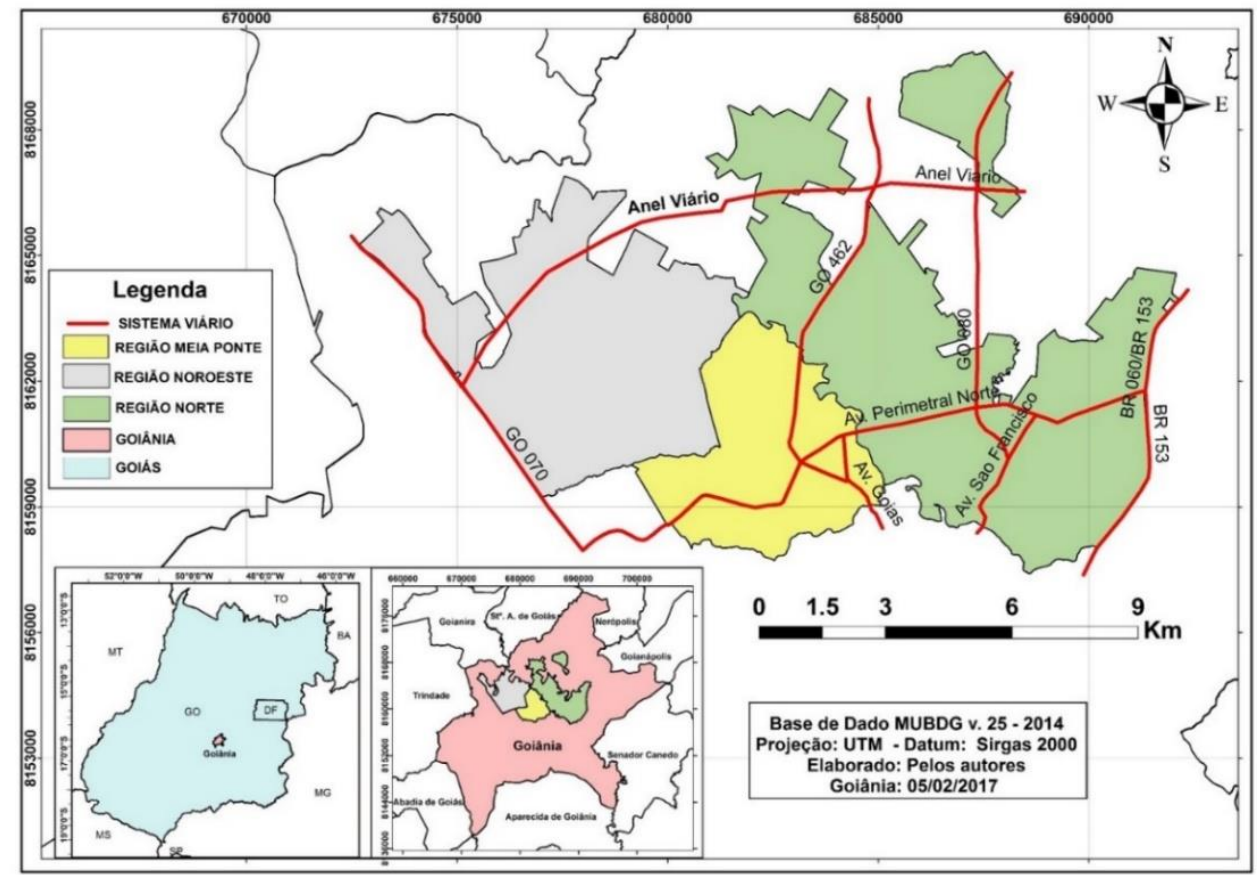

Figura 01: Localização das Regiões Norte, Noroeste e Meia Ponte no Município de Goiânia.

Sete décadas após sua criação, a população da capital, no ano 2.000 superava mais de 20 vezes a projeção de crescimento inicial, alcançando a ordem de 1.093.007 habitantes. Hoje, segundo dados do último censo demográfico do Instituto Brasileiro de 
Geografia e Estatística - IBGE (2010), Goiânia possui certa de mais de 1.302 .000 habitantes, configurando-se, como o município mais populoso da região Centro-Oeste.

Em seu processo de criação, na própria concepção de seu projeto inicial, já era explicita a utopia da burguesia com o desígnio de uma nova ordem social, em razão das condições sociais e econômicas favoráveis a esta classe. Paralelamente, à construção da cidade, ocorreu também um grande fluxo migratório de pessoas em busca de novas oportunidades. Fato este, confirmado por Moysés (2004, p. 17) ao mencionar que, para a construção da nova cidade, vieram trabalhadores dos mais variados lugares do país.

A mão de obra destes operários era indispensável na edificação urbana. À medida que a cidade planejada se desenvolvia, crescia a necessidade de mais trabalhadores para o desenvolvimento da construção civil e para suprir as demais demandas, nos diversos segmentos da sociedade. Seus habitantes eram fazendeiros, camponeses, funcionários públicos transferidos, trabalhadores da construção civil e comerciantes que, ano após ano, configurava um elevado índice populacional urbano, acima da média para os padrões da época (MOYSÉS, 2004).

$\mathrm{O}$ incremento populacional resultou em transformações profundas no espaço urbano da cidade de Goiânia. Em tal fato, é importante frisar, que em seu planejamento inicial previa-se um crescimento organizado e lento, obedecendo ao traçado urbanístico original, que não acorreu.

\section{Periodização para o processo de estruturação do espaço urbano}

De acordo com Oliveira (2002) a cidade de Goiânia já surgiu com o seu espaço tomado pela lógica do valor de troca, e logo assumiria a forma da desigualdade na sua ocupação territorial. Sua consolidação foi fortemente afetada pela estruturação dos conjuntos habitacionais, pelas vilas e loteamentos semiurbanizados, implantados pelo Estado ou, por terrenos, caracterizados como áreas de invasão (MOYSES, 2001).

Seu planejamento sob a ótica da força política e da visão de mundo excludente, por parte da elite goianiense, não produziu quadros técnicos necessários à ocupação da cidade. Desta forma, o espaço urbano de Goiânia e de alguns municípios de sua região metropolitana, para Moysés (2004, p. 195), evidencia a existência de uma cidade fracionada e fragmentada.

Na própria complementação do autor op. cit. (2004) é bem possível identificar a chamada "cidade ilegal", construída à margem da Lei e das instituições, daquela das edificações e loteamentos regulares, aprovados por Lei. Desse modo, as cidades "ilegais" surgem em períodos de calamidades, que revelam a deterioração de seus espaços e as condições precárias que vivem seus moradores (MOYSÉS, 2004, p. 196).

Neste cenário, destaca-se a sua reprodução a partir dos movimentos sociais de reivindicação por direito à moradia. Moraes (2003, p. 196), também corrobora com a análise de tal problemática, quando revela que os marginalizados da "cidade ilegal", os 
sem-teto, ocupavam os terrenos à margem direita do córrego Botafogo". A autora ainda destaca o fenômeno das invasões de terrenos urbanos, como a única alternativa, para os menos favorecidos economicamente, que almejavam residir na capital.

A região noroeste teve a sua ocupação a partir de 1979, com a invasão da Fazenda Caveiras que segundo Moysés (2001), ocorreu em três etapas: a primeira evidenciou-se pela luta por direito à moradia; a segunda foi marcada pela invasão de outras áreas próxima ao Jardim Nova Esperança que recebeu o nome de Jardim Boa Vista e, por último, a ocupação da Fazenda Caveiras que mais tarde denominou-se Jardim Boa Sorte. Estas invasões, como outras, foram marcadas por problemas socioambientais, desigualdade social e alto índice de violência urbana que permanecem até os dias atuais.

Conforme o autor op. cit. (2001) "o Estado age como guardião da propriedade privada, na defesa da ordem burguesa e dos interesses do capital monopolista" (MOYSÉS, 2001 , p. 2). Deste modo, para o autor, foi justamente o Estado que repreendeu o movimento de ocupação de terras nos bairros Jardim Nova Esperança, Jardim Boa Sorte e Jardim Boa Vista.

Ainda segundo o referido autor, as lideranças dos movimentos sociais, nos bairros da região noroeste, foram cooptadas pelo poder público municipal que tomou das mãos dos líderes populares a hegemonia do processo de criação dos lugares. Nesta vertente, Maricato (2003, p.151) questiona o papel da justiça na inobservância da aplicação inadequada e arbitrária das leis, que reforçam a concentração de poder e privilégios e, promove a desigualdade social no território urbano.

Para a década de 80, Moysés (2001) menciona o surgimento dos loteamentos urbanos implantados pelo poder público que deram origem aos bairros: Vila Finsocial, Vila Mutirão I, II e III e os do Jardim Curitiba nas suas quatro etapas (Figura 02). Para o autor, "estes loteamentos, por um lado, se constituíram numa estratégia que tinha como objetivo desmantelar a articulação que se vinha criando em torno da luta pela terra e, por outro lado, acabou também assumindo caráter de segregação social e espacial" (MOYSÉS, 2001, p. 6).

Neste sentido, na década de 90, as lutas pela moradia se intensificaram na porção noroeste de Goiânia. Para Silva (2014), nesse período já se observava mudanças significativas nas condições de moradias da região noroeste, que já eram reivindicadas desde a década de 70. A partir dos primeiros anos da década de 90, alguns bairros foram pavimentados e implantadas as galerias de esgoto pluvial.

Silva (2014) refere-se ainda às obras de infraestrutura em outras partes da cidade, que interligaram a GO-070 à região noroeste, impulsionando o seu desenvolvimento. Dentre as obras implementadas, destaca-se a revitalização da Avenida Anhanguera e da Perimetral Norte que contribuiu, na visão do autor, para a minimização do olhar de contrariedade dos goianienses, para com esta região. Assim, o referido autor (2014) conclui que "esta ocupação tomou um lugar de importância, deixou de ser e estar segregada para apresentar-se como um subcentro urbano, uma nova centralidade, um lugar de possibilidades" (SILVA, 2014, p. 110). 


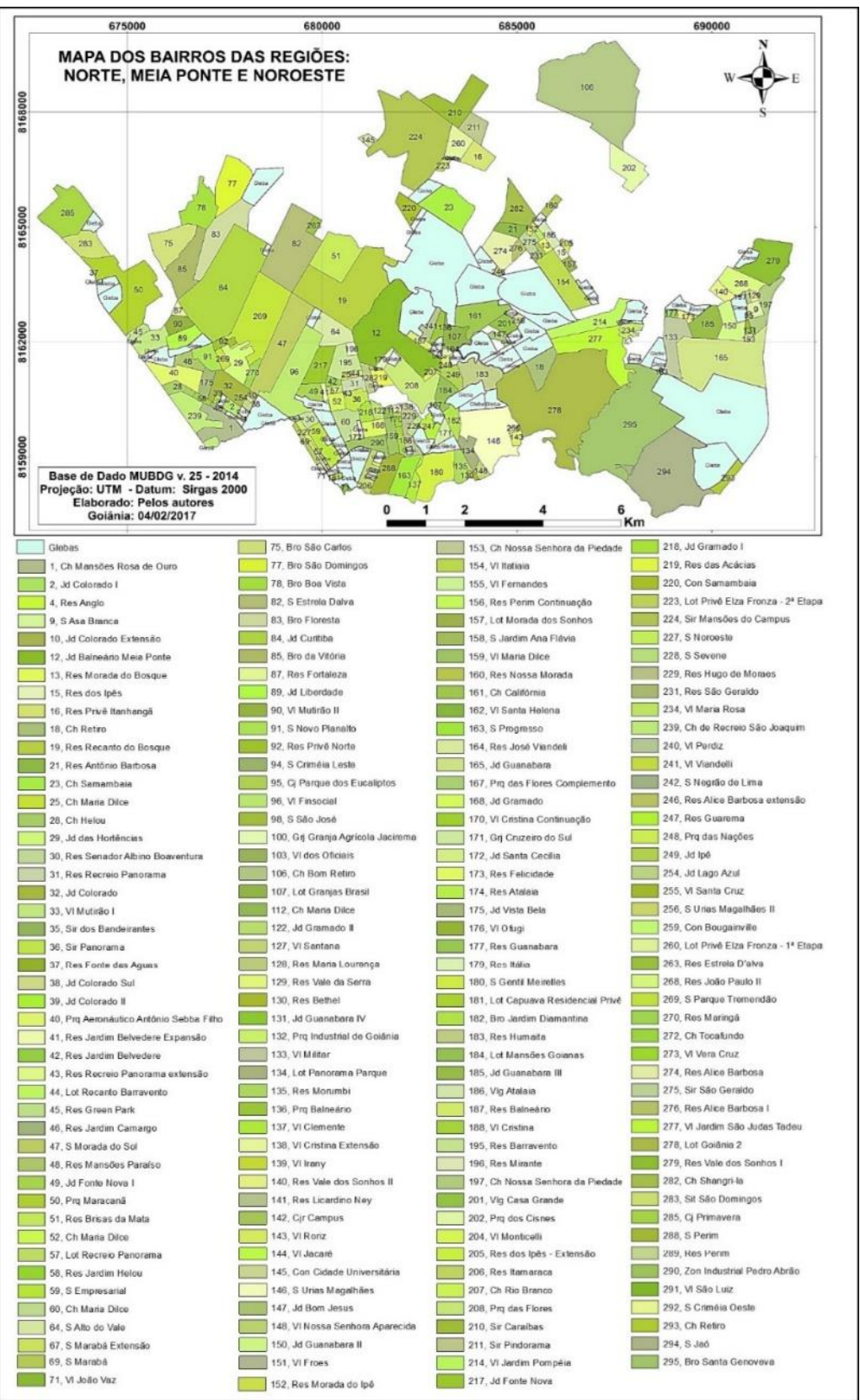

Figura 02: Localização dos bairros /loteamentos das Regiões Norte, Noroeste e Meia Ponte. 
No caso da Região Norte, a sua ocupação significou uma ruptura em relação ao tecido urbano consolidado com a cidade planejada, e sofreu influência da antiga linha ferroviária de Goiânia e das regiões adjacentes (BRANDÃO e PANTALEÃO, 2014). A integração desta região com a Região Noroeste se deu pela construção da Avenida Vera Cruz e da Avenida Guatapará que interligam as Avenidas Perimetral Norte e Goiás.

O surgimento dos bairros da Região Norte está associado à criação das companhias de habitação, remanescentes do Banco Nacional da Habitação (BNH). Segundo Melo (2015) é neste contexto que foram implantados os conjuntos habitacionais Jardim Guanabara (I, II, III e IV). Já para Cardoso (2012), este crescimento da Região Norte não estava planejado, mas, entretanto, Melo (2015) afirma que a criação dos bairros desta região estava prevista no Plano Urbanístico de Goiânia, a fim de implantar um centro de comércio regional, industrial e habitacional para beneficiar a classe trabalhadora.

Em contrapartida, Moysés (2005, p. 5), revela que a região Norte foi diagnosticada no plano de desenvolvimento da cidade de Goiânia, "como inadequada ao parcelamento urbano, devido à problemas geomorfológicos, por ser a região mais bem servida de matas e recursos hídricos, que abastecem a cidade [...] e por possuir as terras mais produtivas do município".

No entanto, na década de 50 ocorreu a transferência do aeroporto de Goiânia que se localizava na região central da cidade, especificadamente no setor aeroporto, para a região Norte. Este fato contribuiu para o surgimento dos bairros Santa Genoveva, Jaó e das demais áreas circunvizinhas (PEREIRA, 2011).

A criação do Conjunto Itatiaia, na região Norte, via iniciativa privada, ocorreu no final da década de 70. Ainda segundo Cardoso (2012), em meados desta década foi criado o Campus Samambaia da Universidade Federal de Goiás (UFG) e, em seguida, os bairros São Judas Tadeu, Itatiaia I, II e III, Jardim Pompéia e a implantação da Central de Abastecimento de Goiás (CEASA). Além destes, instalou-se na região Norte o $10^{\circ}$ Batalhão de Caçadores, posteriormente denominado $42^{\circ}$ Batalhão de Infantaria Motorizada, que atualmente foi transformado na Brigada de Operações Especiais.

A década de 80 foi marcada pelo surgimento do bairro Goiânia II. A expansão da ocupação nesta região ocorreu mediante a implantação de algumas rodovias e vias que favoreceram a instalação de grupos migratórios.

Já no que diz respeito a questão da ocupação da Região do Meia Ponte, esta ao contrário das regiões Norte e Noroeste, parece não estar no centro das discussões sobre o modo irregular de ocupação em Goiânia, tendo em vista o reduzido material bibliográfico disponível. Contudo, a ocupação nesta região seguiu a lógica da periferia, que a envolve pelas porções leste e oeste. Assim, essa região sempre esteve ligada à região Central da capital, sendo ocupada por vários bairros situados nas planícies dos rios Anicuns, Caveirinha e Meia Ponte.

Para Cunha (2007) a forma como os bairros da Região do Meia Ponte se originou, revela também o descaso do Estado, que não agiu adequadamente na regulação do solo 
urbano, previsto no Plano Diretor da cidade. O autor op. cit. (2007) destaca os problemas socioambientais da Vila Roriz, nas proximidades do setor Urias, que foi erguida junto às margens dos rios Anicuns e Meia Ponte, configurando-se em um "aglomerado de exclusão" e de áreas de risco a alagamentos.

Como fator primordial que marcou a explosão demográfica de seus bairros, pode ser apontada a ampliação do traçado da Avenida Goiás Norte, em 1985. Soma-se a esta, a estruturação das Avenidas Nerópolis, Rio Branco e Perimetral Norte. Esta última, considerada uma via expressa, liga a Rodovia Federal BR-153 e à Rodovia Estadual GO - 070, passando por vários bairros da região.

De forma geral, os bairros da Região do Meia Ponte foram implantados em áreas de fazendas, que foram invadidas pela cidade. A exemplo disso, podemos citar o setor Urias Magalhães, um dos mais antigos da região, que teve sua área doada por um fazendeiro, recebendo assim, o seu nome (SEPLAM, 2010).

Vale ainda ressaltar, que segundo a SEPLAM (2010), no princípio da criação da cidade de Goiânia, pensava-se que a ocupação das fazendas localizadas na Região do Meia Ponte, ocorreria de forma rápida. Contudo, isto não aconteceu e, atualmente, alguns bairros da região apresentam um traçado que compartilha o espaço urbano com o rural, mesmo estando situados nas proximidades de bairros centrais, como os bairros Campinas e Universitário.

Em suma, nas três regiões em destaque a evolução de seus bairros atrelada ao próprio processo de loteamento do solo, ocorreu de forma difusa. É notório que muitos destes lotes tendem a distanciarem um dos outros, gerando vazios urbanos, com isolamentos entre eles.

Para Moraes (2003), tal fator revela a prática da reserva de mercado, em áreas de especulação imobiliária. Ainda segundo o autor (2003), foi desta forma que começou à prática perversa de se criar os bolsões de reserva de lotes ou loteamentos, também conhecidos como terra de engorda, com o objetivo de serem mais tarde, comercializados por elevados valores especulativos.

\section{Materiais e métodos}

Para elaboração da pesquisa se fez necessário utilizar a Base Cartográfica (digital), MUBDG (Mapa Urbano Básico de Goiânia), georreferenciada no Sistema UTM - SIRGAS 2000. Inicialmente obteve-se informações da regularização dos loteamentos oriundas da Prefeitura de Goiânia, mais especificamente da Secretaria Municipal de Planejamento e Urbanismo - (SEPLAM/ano base 2016), que é o órgão da administração direta, integrante da estrutura organizacional do Poder Executivo do Município de Goiânia.

Os dados vetoriais dos loteamentos urbanos, com a sua respectiva data de criação, foram geocodificados, para auxiliar no mapeamento do crescimento urbano. Este 
procedimento foi realizado com base na tabela de atributos, que indica a data e o início da implantação de cada loteamento. Todas estas informações deram origem ao Banco de Dados que alimentou a Base Cartográfica Digital. Além destas informações, realizou-se também a interpretações de imagens sensoriais, derivadas de dois tipos diferentes de sensores, sendo um orbital e o outro, suborbital.

As imagens orbitais foram produzidas pela família de satélites Land Remote Sensing Satellite (LANDSAT), versões 1 e 2; sensor Multispectral Scanner System (MSS), versão 5; sensor Thematic Mapper (TM), versão 7; sensor Enhanced Thematic Mapper (ETM) e a versão 8; Operational Land Imager (OLI), dos respectivos anos observados. As imagens do LANDSAT 1, 2, 5 e 7 foram adquiridas dos arquivos do INPE, já as imagens do LANDSAT 8 foram obtidas dos arquivos do serviço Geológico Norte Americano (USGS).

Dos dados suborbitais, obteve-se 176 quadrículas de 1.000 x 1.000 metros com variação em bits de $212 \mathrm{kbs}$ a $30.886 \mathrm{kbs}$, do ano de 2011, junto à Prefeitura de Goiânia. Como resultado, foi gerado um mosaico das fotografias aéreas em um arquivo que depois de compilado alcançou o tamanho de $76 \mathrm{~GB}$, no formato Tiff. Todos estes produtos serviram de base, para a elaboração cartográfica do monitoramento da expansão da malha urbana.

Por fim, para a finalização do mapa temático dos loteamentos regulares e irregulares, foram importadas as informações das condições fundiárias de cada loteamento da área em estudo, para um ambiente de Sistema de Informação Geográfica (SIG), visando a espacialização cartográfica. Em seguida, realizou-se a associação da tabela de atributos das classes temáticas da situação fundiária, com o arquivo vetorial dos loteamentos e glebas. O resultado desta operação gerou um total de 9 classes temáticas, a partir de 313 polígonos representativos das áreas de glebas, loteamentos, chácaras e áreas industriais.

As áreas fundiárias foram divididas em dez classes temáticas, a saber: 1) sem informação; 2) parcelamento em processo de aprovação pela SEPLAM; 3) parcelamento aprovado pela Prefeitura de Goiânia, com publicação de decreto e com registro em cartório; 4) parcelamento aprovado pela Prefeitura com publicação de decreto e sem registro em cartório; 5) parcelamento aprovado por outra organização (Estado de Goiás, INCRA, etc.), com registro em cartório; 6) parcelamento não aprovado por nenhuma organização pública, com registro em cartório; 7) parcelamento não aprovado por nenhuma organização pública, sem registro em cartório; 8) sem uso e; 9) outros (gleba sem parcelamento, conjunto residencial, outros casos). A classificação do parcelamento em irregular ou clandestino está registrada na entidade "ocupações ilegais" (OCI).

\section{Resultados e discussões}

A Figura 03, demostra que na década de 1950 o parcelamento do solo das regiões Norte e do Meia Ponte dava-se principalmente as margens das grandes rodovias como a GO-462, BR-060 e BR-153. Existia na época apenas 30 loteamentos, evoluindo na década 
de 1960, para 41. De acordo com Oliveira (2005), foi neste período que o Estado começou a conceder a criação de loteamentos por parte dos agentes imobiliários. Nota-se, que a partir desta concessão, houve um vertiginoso aumento dos loteamentos nas três regiões em destaque.

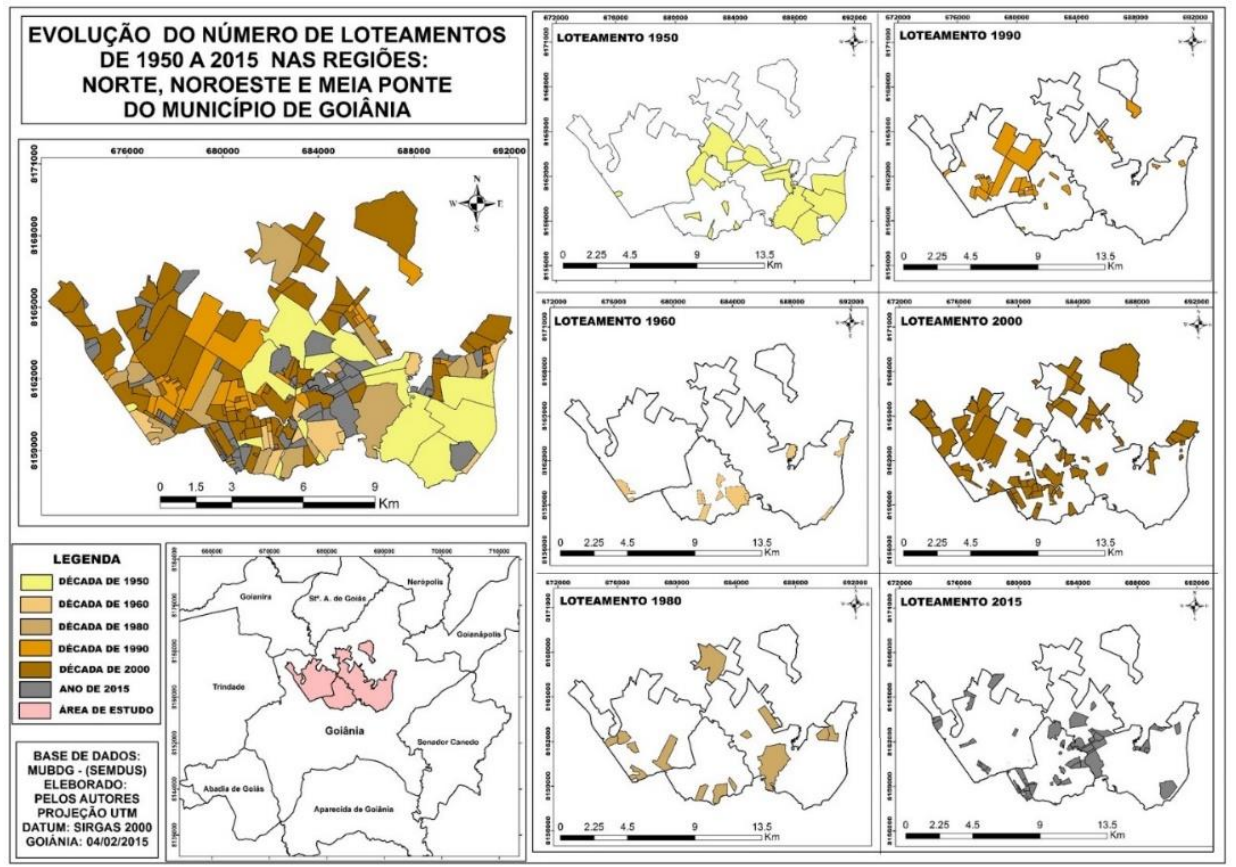

Figura 03: Evolução dos loteamentos nas Regiões Norte, Noroeste e Meia Ponte de Goiânia entre os anos de 1950 até 2015.

No início da década de 1990 já existiam um total de 90 loteamentos, sendo que no ano de 2000, somava-se a estes, mais 88 novos loteamentos, contabilizando um total de 178 . Foi nesta década que a população de Goiânia ultrapassou a marca de um milhão de habitantes, com uma taxa de crescimento expressiva da ordem de 52,01\%, em relação a década anterior.

Já o intervalo entre os anos 2000 a 2015, foi marcado pelo pico do surgimento de novos loteamentos, apresentando 95 novas áreas, somadas a um total de 273 áreas parceladas. Neste período, principalmente na Região do Meia Ponte e na parte central da Região Norte, prevalece a função dos condomínios verticais e dos condomínios horizontais, particulares. Vale ressaltar, que neste levantamento não estão inclusas as glebas e áreas públicas.

A questão da expansão urbana foi acompanhada também a partir do crescimento da malha edificada. Como resposta a esta quantificação foi verificado que no conjunto de ambas as três regiões em destaque, houve uma intensa urbanização, nos últimos 40 anos. A Figura 04 revela à ocorrência deste crescimento urbano, porém é importante destacar 
que tal transformação derivada da expansão demográfica, ficou alheia ao planejamento urbano, previsto para o município.

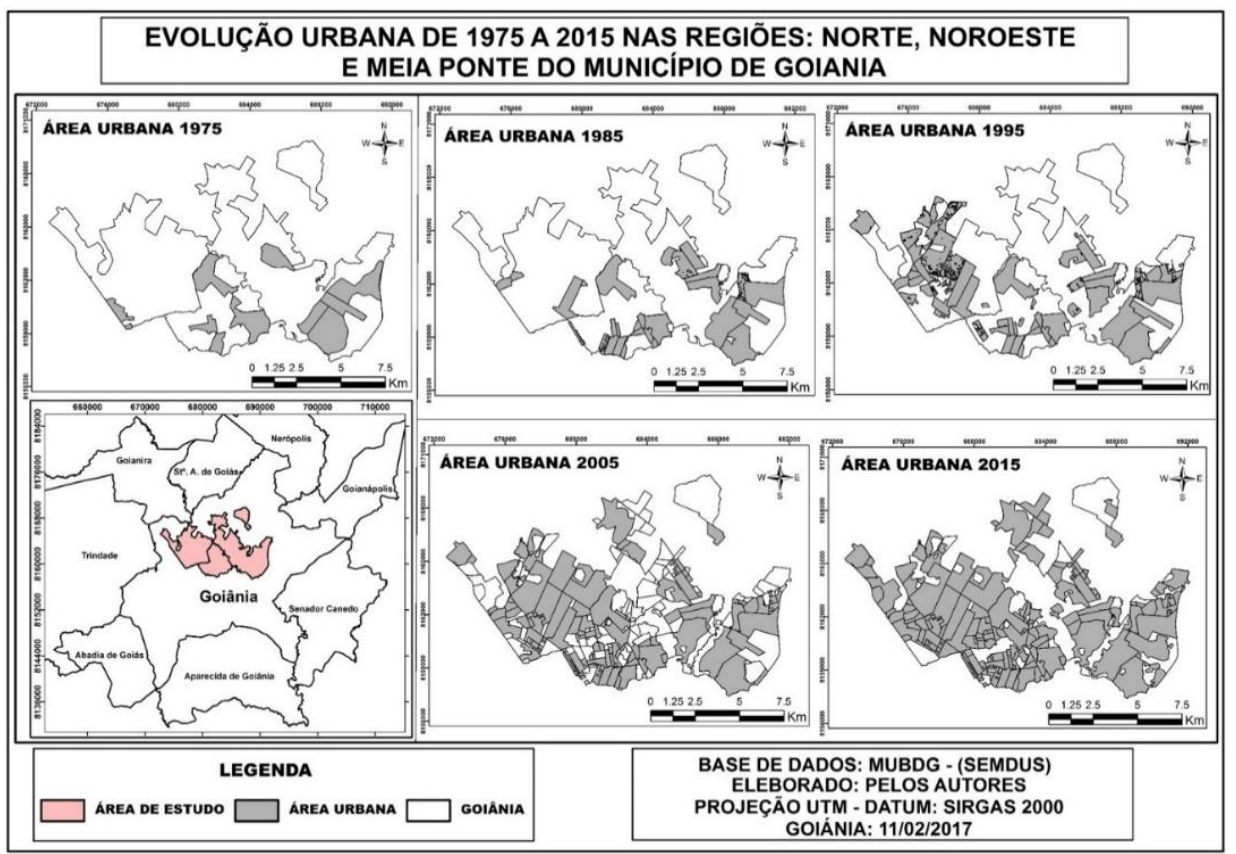

Figura 04: Evolução da malha urbana nas Regiões Norte, Noroeste e Meia Ponte de Goiânia entre os anos de 1975 até 2015.

$\mathrm{Na}$ representação da malha urbano do ano de 1975, é possível identificar a existência de apenas alguns fragmentos de áreas construídas, concentradas na região do Meia Ponte e a sudeste da Região Norte, que somam juntas $18,72 \mathrm{~km}^{2}$, equivalente a 17,18\% da área. Tal índice remetia-se a um quantitativo de 10 bairros, como por exemplo, o Balneário Meia Ponte, Recreio São Domingos, Urias Magalhães, Santa Genoveva, Jardim Guanabara e Campus da UFG, dentre outros, que contribuíram para a consolidação do desenvolvimento urbano destas regiões.

Porém, a partir dos anos subsequentes, notou-se um crescimento gradativo da malha urbana, e no ano de 1985 , a área urbanizada já atingia 22,24\%, o equivalente a 24,23 $\mathrm{km}^{2}$. No ano de 1995, esta, contabilizava-se um extensão de 40,49 km², concomitantemente ao adensamento de loteamentos na Região Noroeste, responsável pelo surgimento de um grande contingente de assentamentos, em conjuntos habtacionais de padrão popular. Já o ano de 2005 foi marcado pela consolidação da ocupação das Regiões Norte e Noroeste. O crescimento foi da ordem de 19,39\%, em relação ao crescimento de 1995. Trata-se dos loteamentos no Setor Mansões dos Campus, Chácara Samambaia, Condomínio Elza Fronza e Parque dos Cisnes. 
Para 2015, a evolução da malha urbana, concentrou na parte central da Região Norte, nas áreas outrora inabitadas. Neste ano, observa-se também o surgimento de bairros mais distantes, dos quais destacam-se aqueles localizados no extremo da área em estudo, como: Cidade Universitária, Setor Caraíba e Residência Privê Pindorama. Assim, finalizando a análise da Figura 04, fica contabilizado que praticamente $73,94 \%$ da área em estudo, está preenchida pela malha urbana edificada.

Outro aspecto de grande relevância que não poderia deixar de ser mencionado é a produção dos conjuntos habitacionais, de vilas e de loteamentos semi-urbanizados, implantados pelo Estado durante a década de 1980. De acordo Moysés (2005), essa foi a fase de ocupação em que o Estado assumiu o papel de protagonista principal.

$\mathrm{Na}$ análise do autor op. cit. (2005), esse processo deu-se em duas etapas. Em um primeiro momento, a intervenção do Estado decorreu muito mais da pressão dos movimentos sociais, do que de uma política deliberada de assentamentos. Num segundo momento, essa intervenção pode ser vista também como uma tentativa do Governo de dar resposta às demandas por habitação. $\mathrm{O}$ Estado passou, progressivamente, a praticar uma política habitacional, porém numa perspectiva de segregação social e espacial.

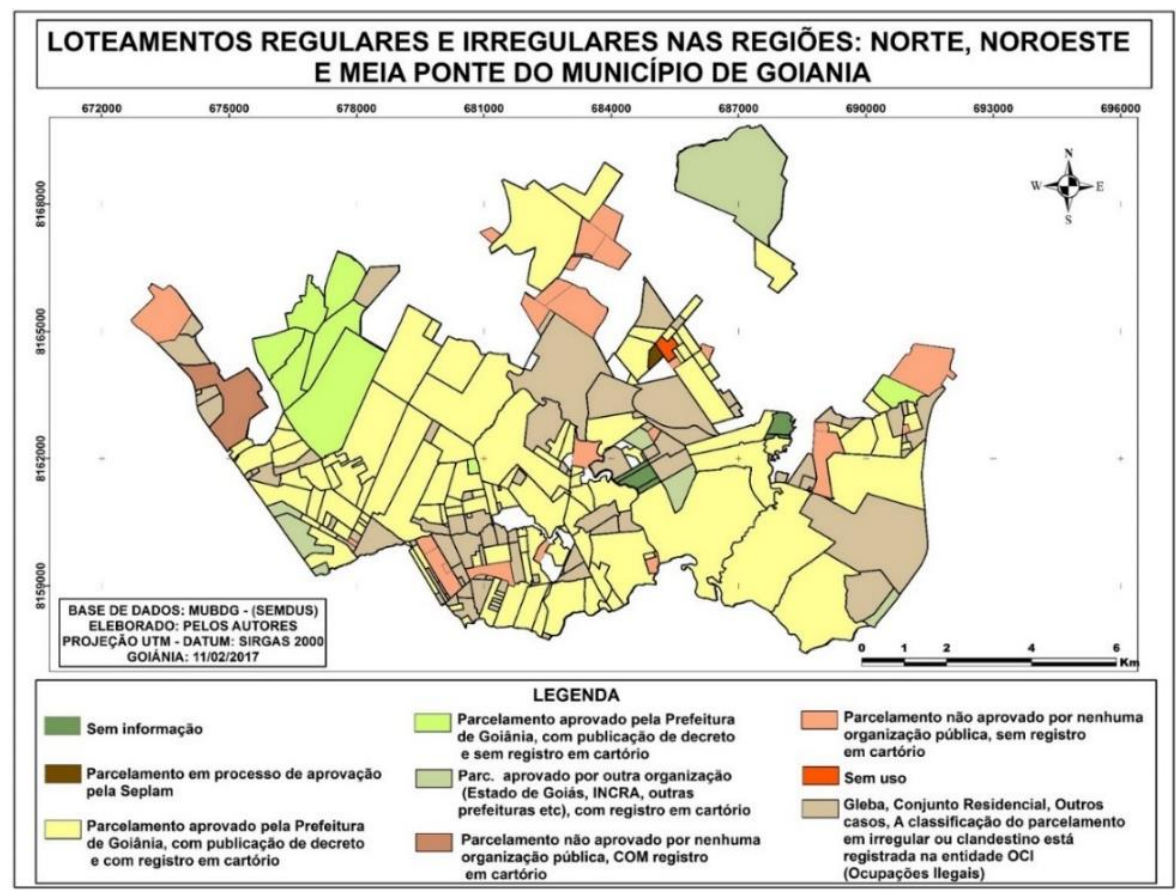

Figura 05: Situação fundiária da área de estudo, localização dos loteamentos regulares, irregulares e em processo de regularização. Base dos dados: MUBDG versão 25 - Prefeitura de Goiânia (2016). 
Ainda segundo Moysés (2005) na tentativa de resolver os problemas da reivindicação a moradia, os loteamentos urbanos implantados pelo Estado foram viabilizados na zona periurbana do município, à revelia da legislação em vigor, desencadeando o surgimento de muitos loteamentos em situação não regularizada e com precários aparatos de equipamentos públicos. Neste sentido vale lembrar as afirmações de Correa (2010), a respeito do processo de segregação, na configuração do espaço urbano de Goiânia. Segundo o referido autor (2010, p. 3), esse processo promoveu o surgimento de vários lugares destinados às diferentes classes sociais, que se contrapõem, se sobrepõem e coadunam.

O atual mapeamento da questão da regularização fundiária, no recorte espacial em destaque, corrobora com as afirmações dos autores mencionados. Tal análise demostra que apesar do esforço do Estado a partir da década de 90, esta situação até hoje não está totalmente resolvida, pois ainda são verificados alguns loteamentos de parcelamentos não aprovados por nenhuma organização pública, com ou sem registros em cartório (Figura $05)$.

Deste modo observa-se na Figura 05, que no período analisado (ano base 2016), haviam 313 polígonos de loteamentos e glebas na área em estudo, desses apenas 47,6\% em situação regular, confirmada junto a prefeitura de Goiânia e aos cartórios de registro de imóveis. Além destes, 8 loteamentos estão aprovados pela prefeitura, mas sem registro em cartório e, apenas um loteamento encontra-se em aprovação junto à SEPLAM.

No Quadro 1 são identificadas 118 glebas e conjuntos residenciais que segundo a Prefeitura de Goiânia, são imóveis das Macrozona Construída ou das Macrozonas Rurais, oriunda de desmembramento de fazendas, que ainda não foi objeto de parcelamento. Incluí nessa classe os conjuntos residenciais, compostos de grupamento de unidades habitacionais unifamiliares, geminadas, seriadas, coletivas ou ainda, mistas entre si, em edificações contínuas ou não, podendo formar vias particulares de acesso interno, com ou sem ocorrência de loteamento, aprovado conforme Lei Específica.

Quadro 01: Situação fundiária na área em estudo.

\begin{tabular}{|l|c|c|c|c|}
\hline \multicolumn{1}{|c|}{ SITUAÇÃO } & $\begin{array}{c}\text { REGĨ̃O } \\
\text { NOROESTE }\end{array}$ & $\begin{array}{c}\text { REGIÃO } \\
\text { MEIA } \\
\text { PONTE }\end{array}$ & $\begin{array}{c}\text { REGIÃO } \\
\text { NORTE }\end{array}$ & TOTAL \\
\hline Sem informação. & 2 & -- & 5 & 7 \\
\hline $\begin{array}{l}\text { Parcelamento em processo de aprovação pela } \\
\text { Seplam. }\end{array}$ & -- & -- & 1 & 1 \\
\hline $\begin{array}{l}\text { Parcelamento aprovado pela Prefeitura de } \\
\text { Goiânia, com publicação de decreto e com } \\
\text { registro em cartório. }\end{array}$ & 42 & 60 & 41 & 143 \\
\hline $\begin{array}{l}\text { Parcelamento aprovado pela Prefeitura de } \\
\text { Goiânia, com publicação de decreto e sem } \\
\text { registro em cartório. }\end{array}$ & 7 & -- & 1 & 8 \\
\hline $\begin{array}{l}\text { Parcelamento Aprovado por outra } \\
\text { organização (Estado de Goiás, INCRA, outras } \\
\text { prefeituras etc.), com registro em cartório. }\end{array}$ & 2 & -- & 4 & 6 \\
\hline \multicolumn{1}{|c|}{} & & & \\
\hline
\end{tabular}




\begin{tabular}{|l|c|c|c|c|}
\hline $\begin{array}{l}\text { Parcelamento não aprovado por nenhuma } \\
\text { organização pública, COM registro em } \\
\text { cartório. }\end{array}$ & 1 & -- & -- & 1 \\
\hline $\begin{array}{l}\text { Parcelamento não aprovado por nenhuma } \\
\text { organização pública, sem registro em } \\
\text { cartório. }\end{array}$ & 3 & 7 & 17 & 27 \\
\hline Sem uso. & -- & 1 & 1 & 2 \\
\hline $\begin{array}{l}\text { Outros - gleba sem parcelamento, conjunto } \\
\text { residencial, outros casos. }\end{array}$ & 32 & 48 & 37 & 118 \\
\hline Total & $\mathbf{8 7}$ & $\mathbf{1 1 6}$ & $\mathbf{1 0 7}$ & $\mathbf{3 1 3}$ \\
\hline
\end{tabular}

Fonte dos dados: Prefeitura de Goiânia / SEPLAM (2016) - organizado pelos autores.

Maricato (2003, p. 153) já chamava atenção para o contraste da cidade formal, concentrada nas regiões nobres e centradas das cidades, onde predominam as leis de zoneamentos, códigos de obras, aprovação do parcelamento do solo e, todas as infraestruturas de serviços básicos necessários desfrutadas pelos que ali residem, com a chamadas cidades periféricas, de "produção dos excluídos". Neste enredo e especificamente para a área em estudo, a Figura 06 traz um panorama do contraste da regularização da cidade formal, com as chamadas cidades periféricas, de concentração dos espaços irregulares.

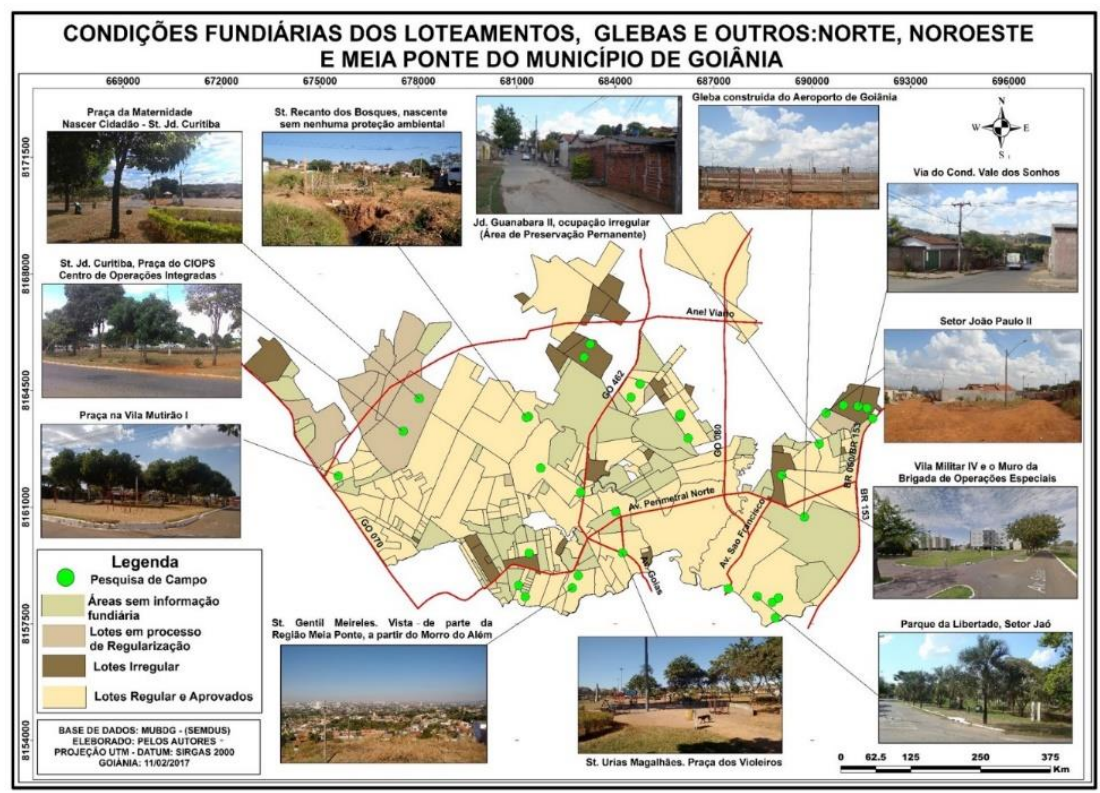

Figura 06. Panorama geral das condições fundiárias dos parcelamentos do solo na área de estudo, localização dos loteamentos regulares, irregulares e em processo de regularização.

Base de dados: MUBDG versão 25 - Prefeitura de Goiânia / SEPLAM (2016). 
Tal contexto nos remete a afirmativa de Moysés e Santos (2009), quando destacam os três atores no processo de ocupação do solo urbano de Goiânia, o Estado, o capital imobiliário e a população mais carente que demanda de espaço por moradias. Segundo os referidos autores (2009), o próprio desenho urbanístico da cidade, confirma e expressa os interesses de seus conflitos sociais:

De um lado, podemos observar o capital imobiliário que impõe seus projetos arquitetônicos, desenha e redesenha espaços que até então pareciam consolidados, cria e recria novas centralidades e, de outro, os movimentos de luta pela casa própria, que se projetam sobre a cidade e deixam uma aparência de que, também são atores que reordenam o espaço urbano. (MOYSÉS e SANTOS, 2009, p. 85).

Reforçando a questão da problemática da informalidade do parcelamento da terra, nos trabalhos feitos in loco (Figura 06), ficou bem evidente que os assentamentos informais, por sua própria natureza se formam sem a observância de qualquer norma de padronização urbanística, resultando em espaços de baixa qualidade de estruturas urbanas. Neste tipo de ocupação é bem comum as ruas estreitas, onde suas vias e calçamentos não tem um padrão geométrico mínimo que permeiam a adequação da instalação de aparatos públicos, para o uso da própria população. Sua infraestrutura é bastante precária e alvo de protestos dos habitantes e de manchetes na mídia, impressa e televisiva.

No Quadro 2 é ilustrada algumas das disparidades que envolve um dos setores mais nobres da Região Norte, o bairro Jaó, em comparação com alguns setores marcados pela proliferação de loteamentos semi-urbanizados, de conjuntos habitacionais de padrão popular, em áreas irregulares ou em processo de regularização. Muitas destas ocupações são promovidas pelo setor público ou provenientes de invasões clandestinas, ocupando em alguns casos, áreas de preservação permanente (APP de cursos d'água). Na maioria, essas áreas irregulares estão sujeitas a precariedade ou ausência de equipamentos públicos, de infraestrutura básica e paisagística.

Quadro 02: Análise de equipamentos comunitários e situação fundiária da área em estudo.

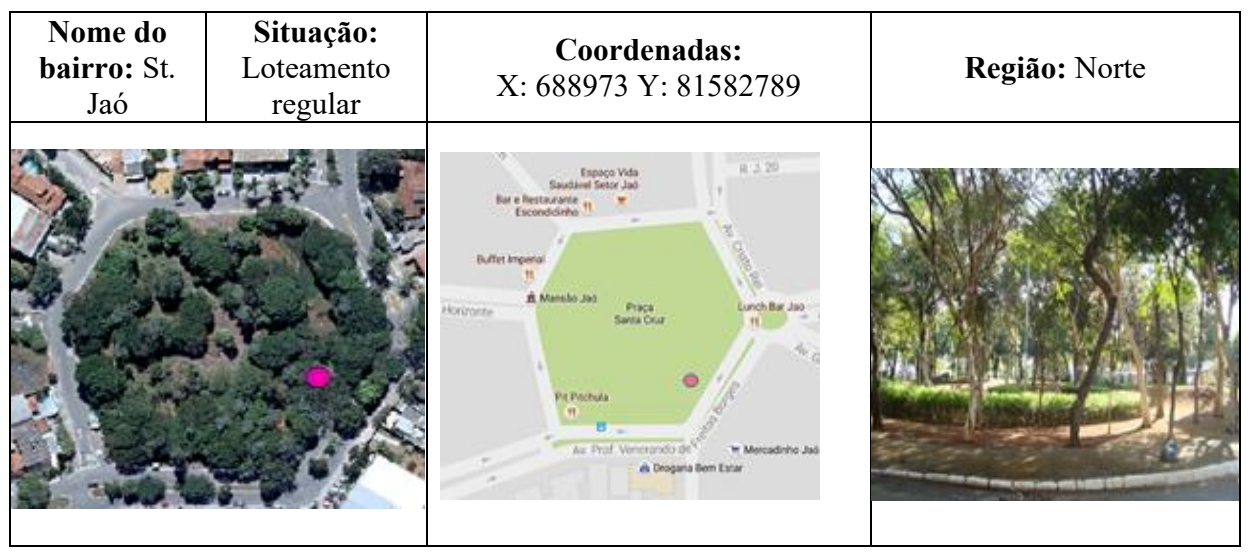




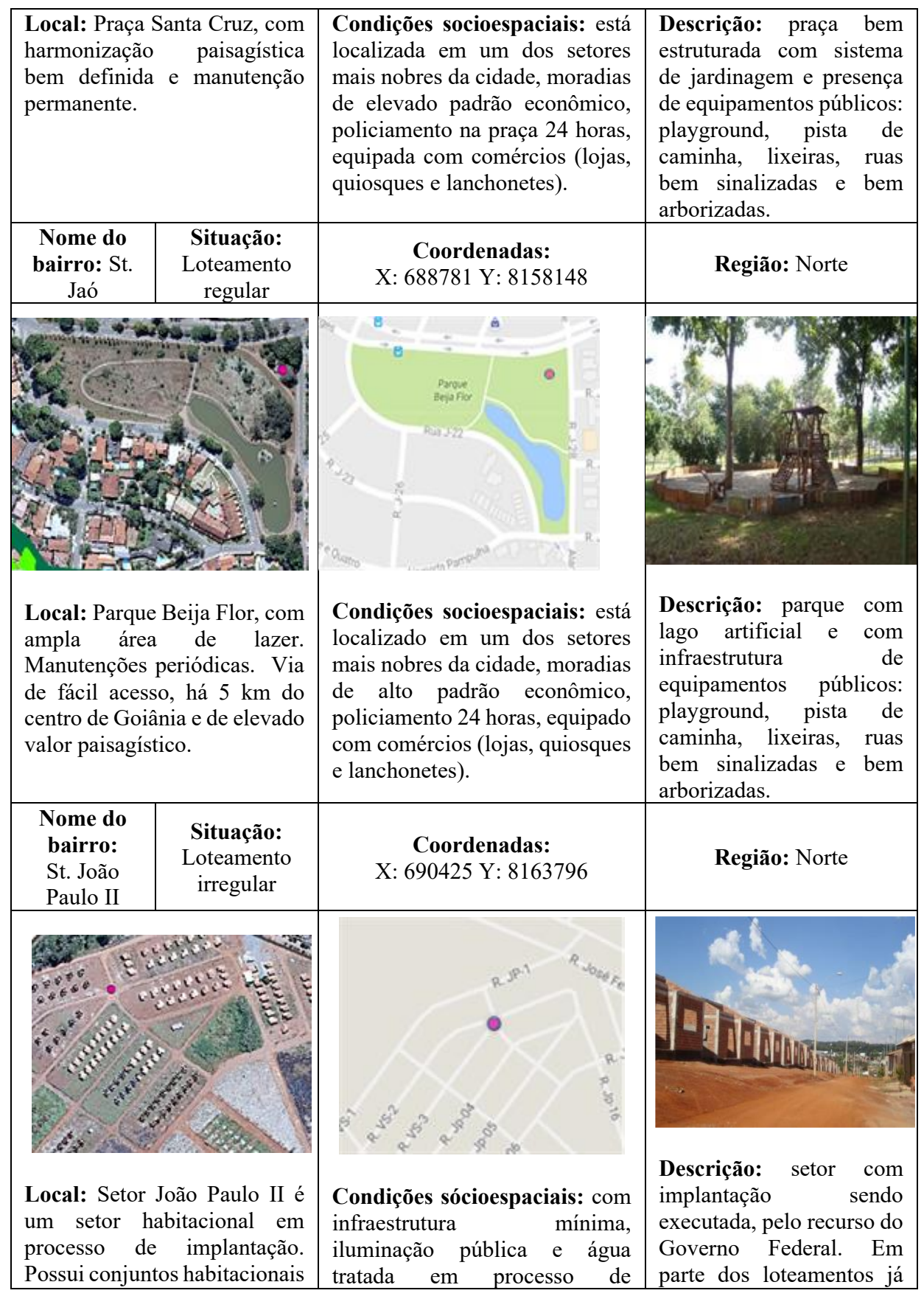




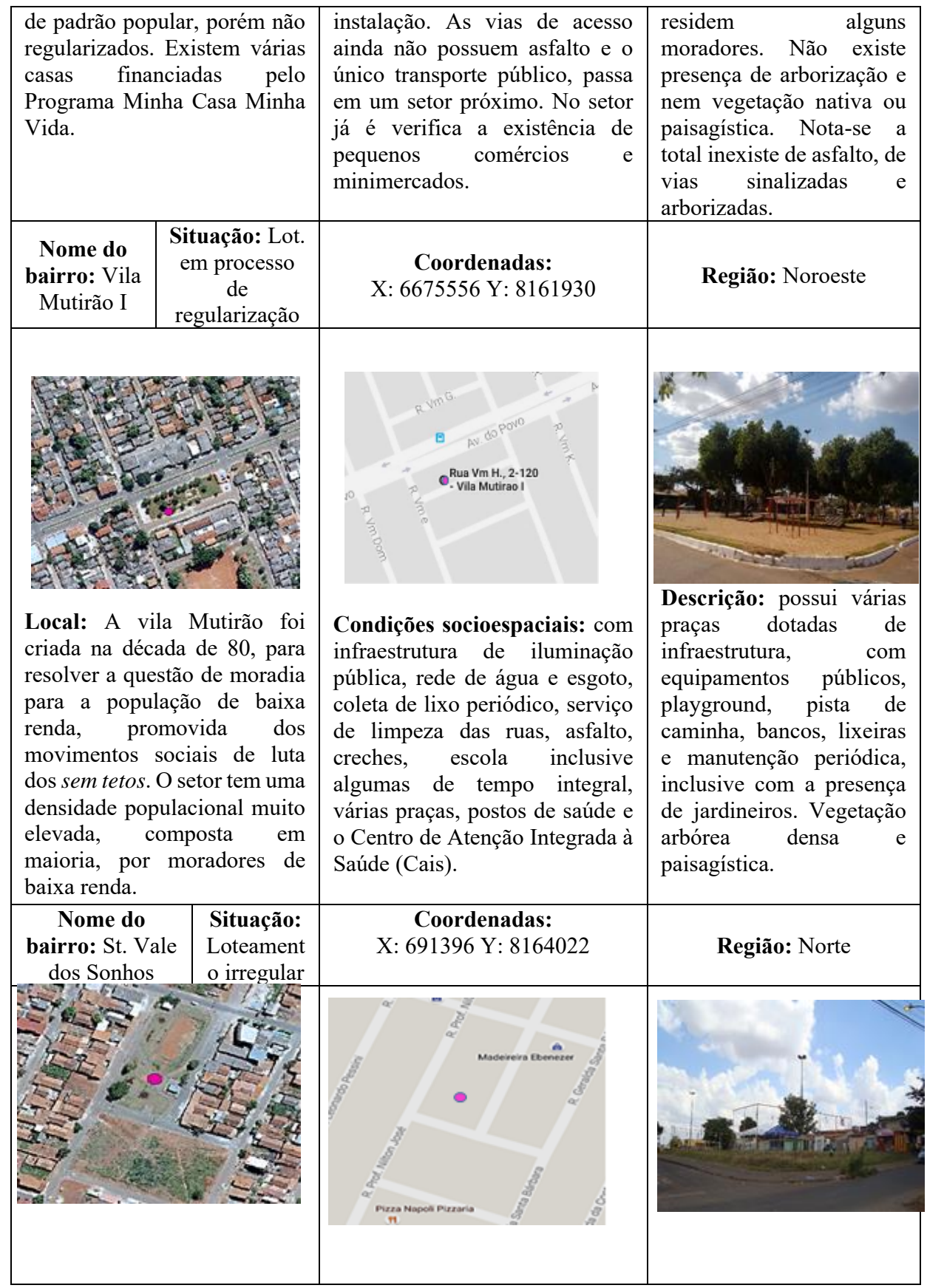




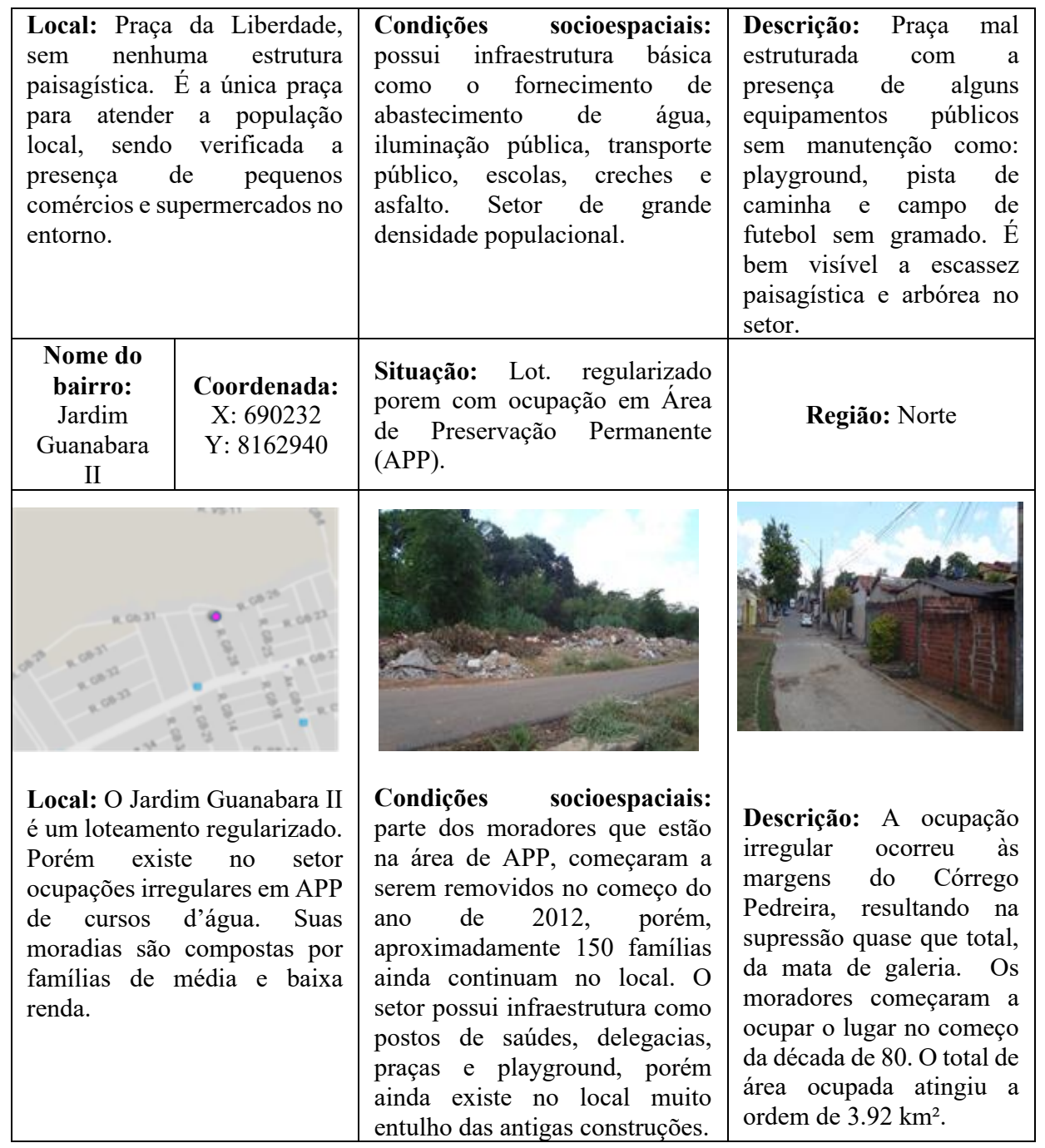

$\mathrm{Na}$ área de APP onde ocorreu a ocupação irregular, existiam aproximadamente 224 domicílios, em um total de 733 pessoas residindo no local. Para a desocupação e demolição de aproximadamente 150 casas, a Prefeitura de Goiânia removeu uma boa parcela dos moradores, transferindo-os para os conjuntos habitacionais Jardins dos Cerrados e Orlando de Morais. Nota-se, que alguns moradores permanecem ainda no local, aguardando sentenças judiciais de indenização ou por não se enquadrarem no perfil econômico, de baixa renda, exigido pela prefeitura para a remoção. 


\section{Considerações finais}

A partir da análise empreendida nesse trabalho, pode-se observar que o processo de urbanização nas regiões Norte, Noroeste e Meia Ponte está diretamente atrelado a insuficiência do poder público administrativo no controle do parcelamento do solo e do déficit habitacional. No contexto histórico de ocupação destas regiões é bem notório que o Estado, na tentativa de ordenador do território, passou, progressivamente, a praticar uma política habitacional, porém dentro de uma perspectiva de segregação social e espacial.

Neste contexto, é visível que as políticas habitacionais adotadas pela Prefeitura de Goiânia, não conseguem acatar, em plenitude, o direito à moradia e de posse legal da terra. $\mathrm{O}$ atual modelo implantado é imediatista, sem planejamento adequado, para atender os anseios das classes menos favorecidas. Além disso, não está totalmente de acordo com o Estatuto da Cidade e de seu Plano Diretor. Como consequências, configuram-se verdadeiras "fabricas de misérias e calamidades sociais", com bairros e vilas sem infraestruturas adequadas para a produção de um espaço urbano de qualidade.

Como resultante de tal processo, ainda é verificada em ambas as três regiões, a dificuldade de alguns de seus moradores quanto a posse e legalização da propriedade. Neste cenário, surgem os denominados loteamentos não aprovados por nenhuma organização pública e sem registro em cartório, sendo na maioria das vezes, ostentados pela dificuldade de seus moradores em custear todas as despesas necessárias à titulação e registro da propriedade.

Outro aspecto constatado e que reflete a insuficiência da eficácia dos instrumentos de regularização fundiária, ainda defrontada pela prefeitura de Goiânia, é a existência de glebas ocupadas sem parcelamento do solo e de alguns loteamentos sem informação da atual situação fundiária junto ao poder público administrativo. Vale frisar que tal situação, remete a insegurança de posse da terra e do direito à moradia, a própria vulnerabilidade do poder público administrativa e da baixa qualidade de vida dos seus ocupantes.

Sem dúvida, as melhorias no modo de vida dos moradores da cidade de Goiânia, bem como o seu acesso as terras urbanizadas, que disponibilizem dos instrumentos necessários a regularização fundiária, direcionada também a população mais carente, implicaria em romper com os privilégios dos modus operandi dos projetos e dos desígnios do capital especulativo imobiliário. O Estado, materializado pela prefeitura, deve fazer valer o que preconiza o Estatuto da Cidade, com vista a garantia do direito à moradia sem distinção e, compatibilizada ao Plano Diretor no que se refere a função social da propriedade.

Por fim, é importante acrescentar, que os benefícios da regularização fundiária vão desde uma determinada área com endereço até a efetivação da gestão pública urbana e de seus benefícios. Soma-se a isso a possibilidade de financiamento para construção e vendas por intermédio de bancos públicos e privados. Assim, na complementação da afirmação de MOYSÉS (2004) e das diretrizes que preveem o direito à moradia de qualidade, a regularização fundiária dos espaços urbanos, visam incorporar a cidade 
clandestina à cidade legal, seja através da previsão de complementação da infraestrutura urbana e/ou da implantação de equipamentos comunitários.

\section{Agradecimentos}

O primeiro autor agradece a FAPEG - Fundação de Amparo à Pesquisa do Estado de Goiás, pela concessão de bolsa de mestrado.

\section{Referências Bibliográficas}

BRASIL. Lei Federal de junho de 2009. Dispõe sobre o Programa Minha Casa, Minha Vida - PMCMV e a regularização fundiária de assentamentos localizados em áreas urbanas. Brasília, 2009. Disponível em < http://www.camara.gov.br/sileg/integras/826725.pdf>. Acesso em: mar. 2016.

BRASIL. Estatuto da Cidade: Lei 10.257/2001 que estabelece diretrizes gerais da política urbana. Brasília, Câmara dos Deputados, 2016. Disponível em $<$ http://www.planalto.gov.br/ccivil_03/leis/LEIS_2001/L10257.htm> Acesso em: ago. 2017

BRANDÃO, Simone B; PANTALEÃO Sandra C. A influência da antiga linha férrea de Goiânia na configuração do tecido urbano dos bairros da região norte. Anais do XIII SHCU -Seminário de História da Cidade e do Urbanismo. Brasília, DF: Universidade Brasília- Faculdade de Arquitetura e Urbanismo, 2014. Disponível em: http://www.shcu2014.com.br/content/influencia-da-antiga-linha-ferrea-goiania-naconfiguracao-do-tecido-urbano-dos-bairros-da> Acesso em: maio 2016.

CARDOSO, Lucimar C. Vaz. Análise socioespacial do Jardim Guanabara. 2012. 106 p. Dissertação de Mestrado em Desenvolvimento e Planejamento Territorial. Pontifícia Universidade Católica de Goiás, Goiânia, abril de 2012. Disponível em $<$ http://tede.biblioteca.ucg.br/tde_busca/arquivo.php?codArquivo=1205>. Acesso em: dez. 2015.

CORRÊA, Eleine A. Lobo. Lugares centrais e lugares periféricos de Goiânia: diversidade e complexidade. Geografia (Londrina), Londrina, v.19, n.2, 2010. Disponível em <http://www.uel.br/revistas/uel/index.php/geografia/article/view/5006>. Acesso em: nov. 2015.

CUNHA, Bernardo C. Colombo da. A Vila Roriz em Goiânia: um maldito exemplo desterritorialização e reterritorialização excludentes. Anais do X EREGEO, Simpósio Regional de Geografia. Abordagens geográficas do Cerrado. Catalão - GO, 6 a 9 de setembro de 2007: UFG, setembro de 2007. Disponível em $<$ https://observatoriogeogoias.iesa.ufg.br/up/215/o/Cunha_bernardo_crist_v_o_colombo _vila_rozin.pdf>. Acesso em: dez. 2015. 
IBGE - Estudo e Pesquisas Informações Geográfica, n 7, 2010. IBGE - Instituto Brasileiro de Geografia e Estatística. Resultados do Universo do Censo Demográfico 2010.

MARICATO, Ermínia. Metrópole, legislação e desigualdade. Revista Estudos Avançados, São Paulo: IEA-USP, v. 17, n. 48, p. 151-167, 2003. Disponível em $<$ http://www.scielo.br/pdf/ea/v17n48/v17n48a13.pdf >. Acesso em: jul. 2016.

MELO, Camila. A. de. Goiânia, crescimento urbano e demandas habitacionais: o caso do Jardim Guanabara. Anais do XXVIII Simpósio Nacional de História. Florianópolis - SC, 27 a 31 de julho de 2015. Disponível em

$<$ http://www.snh2015.anpuh.org/resources/anais/39/1428373207_ARQUIVO_ANPUHJardimGuanabara-Camila.pdf>. Acesso em: nov. 2015.

MORAES, Lúcia M. A Segregação Planejada: Goiânia, Brasília e Palmas. Goiânia: Editora da UCG - Universidade Católica de Goiânia, 2003.

MOYSÉS, Aristides. A produção de territórios segregados na região noroeste de Goiânia: uma leitura sócio-política. Anais II Encontro "Democracia, Igualdade e Qualidade de Vida. O desafio para as cidades no século XXI". Belém - PA, 7 a 9 de outubro 2001. Disponível em

$<$ http://www.observatoriodasmetropoles.ufrj.br/download/arimoyses_tersegreg.pdf $>$. Acesso em: abr. 2016.

MOYSÉS, Aristides. Goiânia: metrópole não planejada. Goiânia: Editora da UCG Universidade Católica de Goiânia, 2004. 420 p.

MOYSÉS, Aristides. Cidade, segregação urbana e planejamento. Goiânia: Editora da UCG - Universidade Católica de Goiânia, 2005. v. 500, 390p.

MOYSÉS, Aristides; SANTOS, Sandra S. R. dos. Cidade, território e requalificação urbana: programa Macambira-Anicuns na metrópole Goianiense. Mercator- Revista de Geografia da UFC, Fortaleza - CE, v. 8, n. 17, p. 79-96, set.- dez. 2009. Disponível em $<$ http://www.mercator.ufc.br/index.php/mercator/article/viewFile/311/257>. Acesso em: mar. 2016.

OLIVEIRA, Adão Francisco de. A Reprodução do Espaço Urbano de Goiânia: uma cidade para o capital. In: OLIVEIRA, Adão Francisco de. Do 'Pântano' ao Jardim, uma Nova Esperança: a produção social do espaço em Goiânia. Dissertação de Metrado. cap. 2. Goiânia- GO. Mestrado em Sociologia da UFG, 2002.

OLIVEIRA, Adão Francisco de. A Reprodução do Espaço Urbano de Goiânia: Uma Cidade para o Capital. In: MOYSÉS, Aristides (org.). Cidade Segregação Urbana e Planejamento. Goiânia: UCG - Universidade Católica de Goiânia, 2005. p. 13-44.

PEREIRA, P. H. M. Aeroporto de Goiânia, parte II. 2011. 16 p. Monografia Graduação em Arquitetura e Urbanismo. Universidade Estadual de Goiás, Goiânia, 2011. 
Disponível em $<$ http://www.unucet.ueg.br/biblioteca/arquivos/monografias/03_PARTE_2_-_Estudos_do_Lugar.pdf $>$ Acessado em: set. 2015.

PREFEITURA MUNICIPAL DE GOIÂNIA. Zoneamento Ecológico Econômico do Município de Goiânia, março de 2008 - Relatório Técnico, disponível: $<$ http://www.goiania.go.gov.br/download/aprovnet/zee/zee_Relatorio_tecnico.pdf $>$. Acesso em: mar. 2016.

SEPLAM, Prefeitura de Goiânia. Coletânea Legislação e regulamentos do Plano Diretor. Secretaria Municipal de Planejamento e Urbanismo - SEPLAM, Goiânia, 2010.

SILVA, Anderson F da. Goiânia À Noroeste: da ocupação ao novo centro urbano. 2014. 130 p. Dissertação de Mestrado em Arquitetura e Urbanismo. Universidade de Brasília Faculdade de Arquitetura e Urbanismo, Brasília, 22 de julho de 2014. Disponível em: http://repositorio.unb.br/bitstream/10482/16610/1/2014_AndersonFerreiradaSilva.pdf. Acesso em: 23/12/2015.

SOARES, Glades Maria J. S. da; BARBOSA, Ycarim M. A realização fundiária de parcelamentos ilegais em Goiânia. EVS- Estudos Vida e Saúde, Universidade Católica de Goiânia, Goiânia, v.39, n. 1, p. 73-81, jan./mar. 2012. Disponível em $<$ http://seer.ucg.br/index.php/estudos/article/view/2368>. Acesso em: abr. 2016.

Helci Ferreira Ramos

Doutorando e Mestre em Geografia pela Universidade Federal de Goiás, Laboratório de Processamento Digital de Imagens e Geoprocessamento - LAPIG da Universidade Federal de Goiás, chefe da Unidade Técnica-Pericial em Geoprocessamento do Ministério Público do Estado de Goiás. Campus Samambaia Caixa Postal 131. Goiânia - GO CAMPUS II Samambaia - Cx. POSTAL 131 - Goiânia - GO / CEP: 74001-970. helcramo@yahoo.com.br

Fabrizia Gioppo Nunes

Doutora em Geologia Ambiental pela Universidade Federal do Paraná e professora efetiva do Instituto de Estudos Socioambientais da Universidade Federal de Goiás. Campus Samambaia Caixa Postal 131. Goiânia-GO CAMPUS II Samambaia - Cx. POSTAL 131 - Goiânia - GO / CEP: 74001-970 fabrizia.iesa.ufg@gmail.com 